\title{
Green Synthesis, Spectral, Thermal Characterization and Biological Activity of Schiff base Ligand Derived from 3-amino-1,2,4-triazol and its Metal Complexes
}

\author{
M M Abdelsalam¹*, Ali M Hassan², Bassem H heakal ${ }^{3}$, M A Bedair ${ }^{2}$, Gamal Abd El Naeem ${ }^{4}$ and Zaghloul I Elbialy ${ }^{1}$ \\ ${ }^{1}$ Egyptian Organization for Standardization and Quality \\ ${ }^{2}$ Chemistry Department, Faculty of Science, Al-Azhar University, Egypt
}

${ }^{3}$ Research Laboratory, Cairo Oil Refining Company, Egypt

${ }^{4}$ The City of Scientific Research and Technology Application, New Borg El-Arab, Alexandria, Egypt

Submission: February 18, 2019; Published: March 14, 2019

"Corresponding author: MM Abdelsalam, Egyptian Organization for Standardization and Quality, Egypt

\begin{abstract}
Green, efficient and clean synthesis of a Schiff base ligand, 1-(((1H-1,2,4-triazol-3-yl) imino) methyl) naphthalen-2-ol (TMN) has been synthesized in equimolar reaction (1:1) of 3-amino-1,2,4-triazole as a primary amine and 2-hydroxy-1-naphthaldehyde as an aldehyde using microwave irradiation technique. The synthesized Schiff base ligand was then reacted with four transition metal ions $\mathrm{Co}(\mathrm{II}), \mathrm{Ni}(\mathrm{II}), \mathrm{Cu}$ (II) and $\mathrm{Zn}$ (II) in 1:1 molar ratio of ligand and metal acetate using microwave technique. The stereochemistry and the bonding characteristics of the ligand and its metal complexes were achieved based on elemental analysis, FT-IR, UV-Vis., NMR and ESR as well as Thermo-Gravimetric Analysis (TGA). The thermal dehydration and decomposition of $\mathrm{Co}$ (II), $\mathrm{Ni}(\mathrm{II})$ and $\mathrm{Cu}(\mathrm{II})$ complexes were studied kinetically using the integral method applying the Coats-Redfern and Horowitz Metzger equations. The antimicrobial activities of ligand and its Zn (II) complex were studied against the bacterial (positive and negative) grams and fungal strains.
\end{abstract}

Keywords: Green chemistry; Microwave irradiation; Schiff base; Triazole; Spectral; Thermal analysis; Biological activity

\section{Introduction}

Nowadays, the protection of our environment and our health is becoming increasingly important due to the worldwide spread of green chemistry. According to the 12 principles of green chemistry [1], preparation and development of environmentally-friendly and harmless products and technologies are the main tasks. In this context, the application of the microwave (MW) technique in organic, inorganic, medicinal, analytical and polymer chemistry has spread fast [2-7]. Microwave-assisted synthesis is acknowledged as a breakthrough in synthetic chemistry in recent years. This technique has overcome the certain back draws associated with conventional routes i.e. larger reaction time, reduced yields and purity and slow rate of reaction. Microwave synthesis provides more opportunities for organic chemists to expand their synthetic avenues by applying microwave irradiation to a variety of organic reactions with improved results [8].

In the nineteenth century, Hugo Schiff, who was born in Germany, prepared a new family of organic compounds, which now have very wide applications plus its massive importance in the development of coordination chemistry. These compounds were known after his name as Schiff bases [9]. These compounds were firstly prepared by the condensation of primary amine $\left(\mathrm{R}_{3}-\mathrm{NH} 2\right)$ with carbonyl compounds aldehydes or ketones having the carbonyl group ( $\mathrm{R} 1 \mathrm{R} 2-\mathrm{C}=0$ ) to produce new compounds having the azomethine group $(-\mathrm{C}=\mathrm{N}-$ ). These compounds are also known as anils, imines or azomethines [10]. The produced compound, $\mathrm{R}_{1} \mathrm{R}_{2} \mathrm{C}=\mathrm{NR} 3$ is called a Schiff base, where $\mathrm{R}_{1}$ is an aryl group, $\mathrm{R}_{2}$ is a hydrogen atom and $R_{3}$ is either an alkyl or aryl group [11-14]. It's also well known that many life activities depend on the heterocyclic compounds, such as purine and pyrimidine bases unit of (DNA and RNA). Five-member N-heterocycle compounds, mainly tetrazole $\left(\mathrm{CH}_{2} \mathrm{~N}_{4}\right)$, Triazoles $\left(\mathrm{C}_{2} \mathrm{H}_{3} \mathrm{~N}_{3}\right)$, and their substituted derivatives [15] are a group of heterocyclic compounds that attracted researchers concern. The presence of three nitrogen hetero-atoms in five-membered ring systems defines an interesting class of compounds, the triazole. This may be of two types, the 1,2,3-triazoles, and the 1,2,4-triazoles. 
1,2,4-Triazole and its derivatives are an imperative type of compounds which possess environmental [16], agricultural [17-19] , industrial [20-22], and biological activities such as antimicrobial [17,23-25], antibacterial [18,26,27], anticancer [28-30], antioxidant $[18,19,31]$, anti-inflammatory $[32,33]$, antiviral $[34,35]$ and many other important applications. In the present study, A Schiff base ligand derived from the reaction between 3-amino-1,2,4-triazole and 2-hydroxy-1-naphthaldehyde and its metal complexes (CoII, NiII, CoII, and ZnII) were synthesized by microwave irradiation as a green approach. All resultant compounds were characterized spectroscopically using different spectroscopic techniques, thermogravimetric analysis and some thermo-kinetic parameter $(\Delta \mathrm{G}, \Delta \mathrm{H}$, and $\Delta \mathrm{S})$ were also calculated. The biological activities of the prepared Ligand and its $\mathrm{Zn}$ (II) were also evaluated.

\section{Experimental}

\section{Chemicals used for Ligand Synthesis}

a) Primary Amine: 3-amino-1, 2, 4-triazole, White powder, Formula: C2H4N4, Mol. Wt: 84.04 g/mol, from Sigma-Aldrich.

b) Aldehydes: 2-hydroxy-1-naphthaldehyde; Linear formula: C11H802, Mol. Wt: 172.18g/mol, color: White, shape: Powder, Furan-2-carboxaldehyde; Linear formula: C5H4O2, Mol. Wt: $96.09 \mathrm{~g} / \mathrm{mol}$, color: yellow, shape: liquid, density: 1.16g/ $\mathrm{ml}$, Thiophene-2-carboxaldehyde; Linear formula: $\mathrm{C5H} 4 \mathrm{OS}$, Mol. Wt: $112.15 \mathrm{~g} / \mathrm{mol}$, color: Brown, Shape: liquid, Density: $1.22 \mathrm{~g} / \mathrm{ml}$, all the above aldehydes were supplied from Sigma-Aldrich.

\section{Metal Salts used for Complexes Synthesis}

The selected metal salts for this purpose; Cobalt (II) acetate tetrahydrate; Linear formula: $\mathrm{Co}\left(\mathrm{CH}_{3} \mathrm{COO}\right)_{2} \cdot 4 \mathrm{H}_{2} \mathrm{O}$, Mol. Wt: 249.08g/mol, color: Violet, shape: Powder, Nickel (II) acetate tetrahydrate Linear formula: $\mathrm{Ni}\left(\mathrm{CH}_{3} \mathrm{COO}\right)_{2} \cdot 4 \mathrm{H}_{2} \mathrm{O}$, Mol. Wt: $248.84 \mathrm{~g} /$ mol, color: Blue-Green, shape: Powder, Copper (II) acetate monohydrate Linear formula: $\mathrm{Cu}\left(\mathrm{CH}_{3} \mathrm{COO}\right)_{2} \cdot \mathrm{H}_{2} \mathrm{O}$, Mol. Wt: $199.65 \mathrm{~g} / \mathrm{mol}$, color: Greenish-Blue, shape: Powder and Zinc (II) Acetate dihydrate; Linear formula: $\mathrm{Zn}\left(\mathrm{CH}_{3} \mathrm{COO}\right)_{2} \cdot 2 \mathrm{H}_{2} \mathrm{O}$, Mol. Wt: $219.51 \mathrm{~g} / \mathrm{mol}$, color: White, shape: Powder, all were supplied from Sigma-Aldrich.

\section{Solvents and other Chemicals}

Distilled water, Methanol, diethyl ether, dimethylformamide (DMF) and dimethyl sulfoxide (DMSO), were of highest purity and used as received without further purification. Ethylenediaminetetraacetic acid (EDTA), murexide, hexamine, eriochrome black T (EBT) indicator, xylenol orange (XO) all of them were of Aldrich or Analar grade quality.

\section{Physical Measurements}

Melting point was measured by electrothermal apparatus and without correction, the electronic absorption spectra (UV-Vis) of ligand and the metal complexes were obtained in DMF solvent from 900-200nm range using Perkin-Elmer Lambda 35 UV/Vis Spectrophotometer fitted with a quartz cell of $1.0 \mathrm{~cm}$ path, the Fou- rier transform infrared spectra of the ligand, as well as the metal complexes dissolved in $\mathrm{KBr}$ were recorded on Vertex 70 Analyzer, Bruker, USA from $4000-400 \mathrm{~cm}^{-1}$ and metal ions estimation was determined by complexometric titration using general lab glassware [36] at the faculty of science, Al-Azhar University, Cairo, Egypt. The magnetic susceptibility of the solid complexes was carried out at room temperature by the Gouy's technique for magnetic susceptibility instrument. The thermogravimetric analyses (TGA) of the solid complexes were performed using the Schimadzu TG-50 thermogravimetric analyzer with a heating rate of $10^{\circ} \mathrm{C} / \mathrm{min}$ under nitrogen atmosphere, in the range of $25-800^{\circ} \mathrm{C}$ at the faculty of sciences, Cairo University. The ESR spectra of the powdered $\mathrm{Cu}^{\text {II }}$ sample were carried out on Bruker-EMX-(Xbands-9.7GHZ) spectrometer with $100 \mathrm{KHZ}$ frequency, microwave power 1.008MW, modulation/amplitude of 4 GAUSSES at National Center for Radiation Research and Technology, Egyptian Atomic Energy Authority.

The elemental analysis for carbon, hydrogen, and nitrogen are carried out using a Flash 2000 organic Elemental Analyzer, Thermo, USA, the mass spectra were performed by an Agilent Technologies-6890N Network GC System and the biological activity evaluation of the synthesized ligand (TMN) and it's Zn (II) complex was determined by using $10 \mathrm{mg} / \mathrm{ml}$ solution in dimethyl sulfoxide (DMSO) at the Regional Center for Mycology and Biotechnology (RCMB) at Al-Azhar University [37] . The ${ }^{1} \mathrm{HNMR}$ and ${ }^{13} \mathrm{CNMR}$ spectra were recorded on an Agilent Technologies model spectrometer NMR400-mercury $400 .{ }^{1} \mathrm{H}$ spectra were run at $300 \mathrm{MHz}$ and ${ }^{13} \mathrm{C}$ spectra were run at $75.46 \mathrm{MHz}$ in dimethylsulphoxide (DMSO-d6). Tetramethyl silane (TMS) was used as an internal reference and chemical shifts are quoted in $\delta(\mathrm{ppm})$ at the Main Chemical Warfare Laboratories, Chemical Warfare Department, Ministry of Defense, Cairo, Egypt. Microwave-assisted reactions conducted on a commercially household microwave energy output $900 \mathrm{~W}$, frequency $2450 \mathrm{MHz}$, manufactured by DAEWOO technologies Corporation, model: KOR-9G2B, Korai.

\section{Microwave Irradiation Method}

\section{Microwave method for the Synthesis of the Schiff Base Ligand (TMN) [36]}

The equimolar ratio (1:1) of 3-amino-1,2,4-triazole (2.44 g, $0.029 \mathrm{~mol}$ ) and 2-hydroxy-1-naphthaldehyde (5.00g,0.029mol) was ground and mixed thoroughly in a grinder until it reached a satisfactory homogeneity. The reaction mixture was then transferred to a clean crucible and moisturized by adding $3-4 \mathrm{ml}$ of methanol as a solvent then transferred to the microwave oven thus irradiated and heated gradually by using on/off cycling to control the temperature. The reaction completed in a short time 1-3 mins at 90-300 watt with higher yields. The products were then recrystallized with hot methanol and finally dried under reduced pressure over anhydrous $\mathrm{CaCl} 2$ in a desiccator. The progress of the reaction and purity of the product was monitored by TLC using silica gel G (yield: 85-95 \%). 
Preparation of the solid Complexes $\mathrm{Co}^{\mathrm{II}}, \mathrm{Ni}^{\mathrm{II}}, \mathrm{Cu}^{\mathrm{II}}$ and $\mathrm{Zn}^{\mathrm{II}}$ [36]

Through complexes formation, the same microwave procedures were applied. The metal salts of the prepared Schiff base ligand, $\mathrm{Co}\left(\mathrm{CH}_{3} \mathrm{COO}\right)_{2} \cdot 4 \mathrm{H}_{2} \mathrm{O}, \mathrm{Ni}\left(\mathrm{CH}_{3} \mathrm{COO}\right)_{2} \cdot 4 \mathrm{H}_{2} \mathrm{O}, \mathrm{Cu}\left(\mathrm{CH}_{3} \mathrm{COO}\right)_{2} \cdot 2 \mathrm{H}_{2} \mathrm{O}$ and $\mathrm{Zn}\left(\mathrm{CH}_{3} \mathrm{COO}\right)_{2} \cdot 2 \mathrm{H}_{2} \mathrm{O}$ were mixed in (1:1) ratio. The reaction mixtures were then irradiated by the microwave oven by adding
$1-3 \mathrm{ml}$ of methanol as a solvent. The reaction completed in a short time (5-10min) with higher yields. The obtained products were washed by hot methanol and ether then finally dried under reduced pressure over anhydrous $\mathrm{CaCl}_{2}$ in a desiccator. The progress of the reaction and purity of the products were monitored by TLC using silica gel G (yield: 70-90\%), The physical properties of the metal complexes are listed in (Table 1).

Table 1: Analytical and physical properties of the prepared compounds.

\begin{tabular}{|c|c|c|c|c|c|c|c|c|c|c|}
\hline \multirow{2}{*}{ Symbol } & \multirow{2}{*}{ Molecular Formula } & \multirow{2}{*}{$\mathbf{m} \cdot \mathbf{p}^{\circ} \mathrm{C}$} & \multirow{2}{*}{ Yield \% } & \multirow{2}{*}{$\begin{array}{c}\text { Time } \\
\text { min }\end{array}$} & \multirow{2}{*}{ Color } & \multicolumn{4}{|c|}{ Elemental Analysis Calc. / (Found) \% } & \multirow{2}{*}{$\begin{array}{c}\text { M+ Calc./ } \\
\text { (Found) }\end{array}$} \\
\hline & & & & & & $\mathrm{C}$ & $\mathrm{H}$ & $\mathrm{N}$ & $\mathrm{M}$ & \\
\hline TMN & $\mathrm{C}_{13} \mathrm{H}_{10} \mathrm{~N}_{4} \mathrm{O}$ & 260 & 91 & 3 & Yellow & $\begin{array}{c}66.43 \\
(65.54)\end{array}$ & $\begin{array}{c}5.23 \\
(4.23)\end{array}$ & $\begin{array}{c}22.11 \\
(23.52)\end{array}$ & - & $\begin{array}{c}238.06 \\
(238.09)\end{array}$ \\
\hline Co & $\mathrm{C}_{15} \mathrm{H}_{18} \mathrm{CoN}_{4} \mathrm{O}_{6}$ & $>360$ & 88 & 5 & $\begin{array}{c}\text { Reddish } \\
\text { Brown }\end{array}$ & $\begin{array}{c}40.13 \\
(42.17)\end{array}$ & $\begin{array}{c}3.8 \\
(4.72)\end{array}$ & $\begin{array}{c}(14.2) \\
(13.11)\end{array}$ & $\begin{array}{c}12.96 \\
(13.79)\end{array}$ & 427.28 \\
\hline $\mathrm{Ni}$ & $\mathrm{C}_{15} \mathrm{H}_{16} \mathrm{~N}_{4} \mathrm{NiO}_{5}$ & $>360$ & 56 & 5 & Brown & $\begin{array}{c}40.24 \\
(46.03)\end{array}$ & $\begin{array}{c}3.74 \\
(4.09)\end{array}$ & $16.1(14.32)$ & $\begin{array}{l}14.6 \\
(15)\end{array}$ & 391 \\
\hline $\mathrm{Cu}$ & $\mathrm{C}_{15} \mathrm{H}_{16} \mathrm{CuN}_{4} \mathrm{O}_{5}$ & $>360$ & 85 & 6 & Olive & $\begin{array}{c}40.05 \\
(45.51)\end{array}$ & $\begin{array}{c}4.65 \\
(4.07)\end{array}$ & $\begin{array}{c}14.37 \\
(14.15)\end{array}$ & $\begin{array}{c}14.83 \\
(16.05)\end{array}$ & 395.86 \\
\hline $\mathrm{Zn}$ & $\mathrm{C}_{15} \mathrm{H}_{16} \mathrm{~N}_{4} \mathrm{O}_{5} \mathrm{Zn}$ & $>360$ & 71 & 6 & Orange & $\begin{array}{c}43.34 \\
(45.30)\end{array}$ & $\begin{array}{c}4.36 \\
(4.06)\end{array}$ & 13.4814 .09 & $\begin{array}{c}16.4 \\
(16.44)\end{array}$ & 397.7 \\
\hline
\end{tabular}

\section{Procedure for Antibacterial Activity}

\section{Antibacterial and Fungi studies}

The Schiff base ligand (TMN) and its respective $\mathrm{Zn}$ (II) complex were tested and evaluated for their antimicrobial activity using the agar diffusion technique (Cooper, 1972) [37]. $5 \mathrm{mg} / \mathrm{ml} \mathrm{solu-}$ tion in dimethyl sulfoxide was used. The tested organisms were Gram-negative bacteria (Escherichia Coli (RCMB 010052) ATCC 25955\& Salmonella typhimurium RCMB 006 (1) ATCC 14028), Gram-positive bacteria (Bacillus subtilis, RCMB 015 (1) NRRL B-543\& Staphylococcus aureus, RCMB010010) and fungi (Aspergillus flavus, RCMB 002008) \& Candida albicans RCMB 005003 (1) ATCC 10231). The bacteria and fungi were maintained on nutrient agar medium and Czapeks Dox agar medium, respectively. DMF showed no inhibition zones. The agar media were inoculated with different test microorganism. After $24 \mathrm{hrs}$. of incubation at $37^{\circ} \mathrm{C}$ for bacteria and $48 \mathrm{hrs}$. of incubation at $28^{\circ} \mathrm{C}$ for fungi, the diameter of inhibition zone ( $\mathrm{mm}$ ) was measured.

\section{Results and Discussion}

\section{Characterization of the Prepared Compounds}

All compounds containing the six and four-member rings with (-N- heterocycle) as shown in scheme 1 azomethine and hydroxyl groups possess basic characteristics due to the presence of lone pair electron-donating character of the double bond of $(-\mathrm{HC}=\mathrm{N})$ and the capability to form metal complexes. The basic strength of the $\mathrm{C}=\mathrm{N},(-\mathrm{N}$ heteroatom $)$ and $-\mathrm{OH}$ groups is insufficient solely to allow the formation of stable complexes by simple coordination of the lone pair to a metal ion. Therefore, a metal ion will attack the $-\mathrm{N}$ hetero and -OH groups to form six and four-membered rings for the prepared. The proposed structures of the prepared Schiff base ligand have been confirmed based on the following techniques:

\section{IR Spectra}

The important infrared bands exhibited by the Schiff-base ligand and its complexes are given in Table 2 . The ligand possessed potential donor sites like azomethine linkage $(-\mathrm{C}=\mathrm{N})$, triazole ring nitrogen $(-\mathrm{C}=\mathrm{N})$ and hydroxyl $(-\mathrm{OH})$ group. The IR spectra of the ligand showed peaks at 3107, 1575 and $1088 \mathrm{~cm}^{-1}$ respectively due to vibration of $(\mathrm{N}-\mathrm{H}),(\mathrm{C}=\mathrm{N})$ and $(\mathrm{N}-\mathrm{N})$ of triazole moiety. Originally, 3-amino-1,2,4-triazole and aldehydes showed peaks at 3325 and $1715 \mathrm{~cm}^{-1}$ respectively, due to amino $\left(\mathrm{NH}_{2}\right)$ and aldehydic (CHO) group vibrations. In the spectra of the ligand, the peaks at 1715 and $3325 \mathrm{~cm}^{-1}$ due to aldehydic (CHO) and amino $\left(\mathrm{NH}_{2}\right)$ groups of the original moieties were completely disappeared and in turn, a new sharp band appeared at $1619 \mathrm{~cm}^{-1}$ assigned to the azomethine $(-\mathrm{C}=\mathrm{N})$ linkage [39]. The IR spectra of ligand showed bands at $1088 \mathrm{~cm}^{-1}$ for triazole (N-N), $1370 \mathrm{~cm}^{-1}$ for (C-O), 1525 $\mathrm{cm}^{-1}$ for $(\mathrm{C}=\mathrm{C}), 1575 \mathrm{~cm}^{-1}$ for triazole $(\mathrm{C}=\mathrm{N}), 1619 \mathrm{~cm}^{-1}$ for azomethine $(\mathrm{C}=\mathrm{N}), 2885 \mathrm{~cm}^{-1}$ for aliphatic $(\mathrm{C}-\mathrm{H}), 3029 \mathrm{~cm}^{-1}$ for Aromatic (C-H), $3107 \mathrm{~cm}^{-1}$ for triazole (N-H), $3441 \mathrm{~cm}^{-1}$ for phenolic $(\mathrm{O}-\mathrm{H})$. The comparison of the IR spectra of Schiff base ligand with corresponding metal complexes gave a different mode of absorption in complexation of the ligand with the metal ions. For ligand (TMN), the disappearance of a broad band of $\mathrm{v}(\mathrm{OH})$ at $3441 \mathrm{~cm}^{-1}$ in spectra of metal complexes and in turn appearance of new band assigned to (C-O) at 1387-1251 $\mathrm{cm}^{-1}$ revealed deprotonation and coordination of hydroxyl-0 to the metal atom.

The coordination of metal to oxygen is further justified by the appearance of a new band at $459-445 \mathrm{~cm}^{-1}$ due to M- 0 . For all 
the metals (II) complexes, a new band appeared at 595-565 $\mathrm{cm}^{-1}$ due to $v(M-N)$ vibrations indicating the coordination of nitrogen of (azomethine and triazole) with the metal ions. However, the IR band observed at $1088-1015 \mathrm{~cm}^{-1}$ in triazole ring is assigned to $v(\mathrm{~N}-\mathrm{N})$ mode remained unchanged in the spectra of all the metal complexes thus indicating the non-involvement of nitrogen of $(\mathrm{N}-\mathrm{N})$ of triazole ring. The $\mathrm{C}=\mathrm{N}$ stretch shows both a positive and negative shift on complexation. We have observed a positive shift of azomethine to lower frequency at $(1610-1617) \mathrm{cm}^{-1}$ for all complexes the involvement of the azomethine- $\mathrm{N}$ in the complex formation. The IR spectra of ligand and its metal (II) complexes conclusively showed that the ligand coordinates to the metal atoms bi and tri-tentative the azomethine- $\mathrm{N}$, triazole- $\mathrm{N}$, and hydroxyl-O groups. Other bands ascribed to negative acetate ion (OAc) were detected in all specimens at $1438-1425 \mathrm{~cm}^{-1}$ suggesting carboxylic modes (Table 2).

Table 2: Significant FT-IR of the prepared compounds.

\begin{tabular}{|c|c|c|c|c|c|c|c|c|c|c|c|}
\hline Comp & $\begin{array}{l}\mathrm{v}(\mathrm{OH}) \\
\left(\mathrm{H}_{2} \mathrm{O}\right)\end{array}$ & $v(\mathrm{NH})$ & $\begin{array}{c}v(\mathrm{C}-\mathrm{H}) \\
\text { Ar/Alph }\end{array}$ & $\begin{array}{c}v(\mathrm{C}=\mathrm{N}) \\
\text { azo- } \\
\text { meth- } \\
\text { ane }\end{array}$ & $\begin{array}{l}v(\mathrm{C}=\mathrm{N}) \\
\text { triazole }\end{array}$ & $v(C=C)$ & $\begin{array}{c}v(\mathrm{OA} \chi) \\
\alpha \sigma / \sigma\end{array}$ & $v(C-0)$ & $v(N-N)$ & $v(M-N)$ & $v(M-0)$ \\
\hline TMN & 3441 & 3107 & 2948 & 1619 & 1575 & 1525 & - & 1325 & 1088 & - & - \\
\hline $\mathrm{Co}^{\mathrm{II}}$ & 3374 & 3145 & 3050 & 1611 & 1574 & 1538 & 1438 & 1299 & 1090 & 557 & 445 \\
\hline $\mathrm{Ni}^{\mathrm{II}}$ & 3373 & - & 3052 & 1614 & 1582 & 1537 & 1425 & 1296 & 1088 & 556 & 457 \\
\hline \multirow{2}{*}{$\mathrm{Cu}^{\mathrm{II}}$} & \multirow{2}{*}{3407} & \multirow{2}{*}{-} & 3050 & \multirow{2}{*}{1610} & \multirow{2}{*}{1577} & \multirow{2}{*}{1537} & \multirow{2}{*}{1432} & \multirow{2}{*}{1387} & \multirow{2}{*}{1096} & \multirow{2}{*}{595} & \multirow{2}{*}{459} \\
\hline & & & 2956 & & & & & & & & \\
\hline \multirow{2}{*}{$\mathrm{Zn}^{\mathrm{II}}$} & 3415 & \multirow{2}{*}{3114} & \multirow{2}{*}{3062} & \multirow{2}{*}{1617} & \multirow{2}{*}{1575} & \multirow{2}{*}{1540} & \multirow{2}{*}{1428} & \multirow{2}{*}{1297} & \multirow{2}{*}{1088} & \multirow{2}{*}{557} & \multirow{2}{*}{450} \\
\hline & 3401 & & & & & & & & & & \\
\hline
\end{tabular}

\section{Electronic spectra and Magnetic Properties}

Table 3: Spectral and magnetic data of the prepared compounds.

\begin{tabular}{|c|c|c|c|c|c|c|c|}
\hline Comp. & $\lambda_{\text {max }}, \mathbf{n m}$ & Assignments & $\mu_{\text {eff }}(\mathrm{BM})$ & $g^{\wedge}$ & $\mathbf{g} \backslash \backslash$ & $\mathbf{g}_{\mathrm{av}}$ & $\begin{array}{l}\text { Suggested } \\
\text { Structure }\end{array}$ \\
\hline \multirow{3}{*}{ TMN } & 362 & $\left(n-\pi^{*}, C=N\right)$ & \multirow{3}{*}{-} & \multirow{3}{*}{-} & \multirow{3}{*}{-} & \multirow{3}{*}{-} & \multirow{3}{*}{-} \\
\hline & 320 & $\left(\pi-\pi^{*}, C=N\right)$ & & & & & \\
\hline & 242 & ( $\pi-\pi^{*}$, aromatic ring) & & & & & \\
\hline \multirow{2}{*}{ Co } & 450 & ${ }^{4} \mathrm{~T}_{1} \mathrm{~g}(\mathrm{~F}) \rightarrow{ }^{4} \mathrm{~T}{ }_{1} \mathrm{~g}(\mathrm{P})$ & \multirow{2}{*}{5.12} & \multirow{2}{*}{-} & \multirow{2}{*}{-} & \multirow{2}{*}{-} & \multirow{2}{*}{ Octahedral } \\
\hline & 525 & ${ }^{4} \mathrm{~T}{ }_{1} \mathrm{~g}(\mathrm{~F}) \rightarrow{ }^{4} \mathrm{~T}_{2} \mathrm{~g}$ & & & & & \\
\hline \multirow{2}{*}{$\mathrm{Ni}$} & 500 & ${ }^{3} \mathrm{~T}_{1}(\mathrm{~F}) \rightarrow{ }^{3} \mathrm{~A}_{2}$ & \multirow{2}{*}{2.73} & \multirow{2}{*}{-} & \multirow{2}{*}{-} & \multirow{2}{*}{-} & \multirow{2}{*}{ Tetrahedral } \\
\hline & 650 & ${ }^{3} \mathrm{~T}_{1}(\mathrm{~F}) \rightarrow{ }^{3} \mathrm{~T}_{1}(\mathrm{P})$ & & & & & \\
\hline \multirow{2}{*}{$\mathrm{Cu}$} & 650 & \multirow{2}{*}{${ }^{2} \mathrm{~B}_{2} \rightarrow 2 \mathrm{E}$} & \multirow{2}{*}{1.78} & \multirow{2}{*}{2.198} & \multirow{2}{*}{2.05} & \multirow{2}{*}{2.15} & \multirow{2}{*}{ Tetrahedral } \\
\hline & 425 & & & & & & \\
\hline \multirow{2}{*}{$\mathrm{Zn}$} & 500 & \multirow{2}{*}{$\mathrm{M} \rightarrow \mathrm{L}$} & \multirow{2}{*}{ Dia. } & \multirow{2}{*}{-} & \multirow{2}{*}{-} & \multirow{2}{*}{-} & \multirow{2}{*}{ Tetrahedral } \\
\hline & 675 & & & & & & \\
\hline
\end{tabular}

The electronic absorption spectra of the Schiff-base ligand and its complexes are shown in Figure 1. and were performed in dimethylformamide (DMF). The position of the band maxima and the magnetic moment values of the prepared complexes are mentioned in Table 3. The electronic spectra of ligand (TMN) showed three absorption bands at $370-385 \mathrm{~cm}^{-1}$ refers to $\mathrm{n} \pi^{*}$, of $\mathrm{C}=\mathrm{N}$ triazole and 0 -hydroxyl group, respectively. And at 335 $\mathrm{cm}^{-1}$ refers to $\pi \pi^{*}$, of $\mathrm{C}=\mathrm{N}$ azomethane. The third band was at 265 $\mathrm{cm}^{-1}$ refers to $\pi \pi^{*}$, of $\mathrm{C}=\mathrm{C}$ phenyl. The electronic spectra of Co (II) complex showed two absorption bands at $(450,525) \mathrm{nm}$ assigned to ${ }^{4} \mathrm{~T} 1 \mathrm{~g}(\mathrm{~F}) \rightarrow{ }^{4} \mathrm{~T} 1 \mathrm{~g}(\mathrm{P})$ and ${ }^{4} \mathrm{~T} 1 \mathrm{~g}(\mathrm{~F}) \rightarrow{ }^{4} \mathrm{~T} 2 \mathrm{~g}$ transitions, respectively. The observation of these bands suggests an octahedral configuration around CoII ion, and the complex is paramagnetic, and the magnetic moment is $5.12 \mathrm{BM}$. For Ni (II) complex, the electronic spectra showed bands of appreciable intensity at $(500,650) \mathrm{nm}$ and were assigned to ${ }^{4} \mathrm{~T} 1 \mathrm{~g}(\mathrm{~F}) \rightarrow{ }^{4} \mathrm{~T} 1 \mathrm{~g}(\mathrm{P})$ and ${ }^{4} \mathrm{~T} 1 \mathrm{~g}(\mathrm{~F}) \rightarrow{ }^{4} \mathrm{~T} 2 \mathrm{~g}$ suggests a tetrahedral structure, and the magnetic moment is 2.73 B.M. For Cu (II) complex, the electronic spectra showed bands of appreciable intensity at $(450,650) \mathrm{nm}$ assigned to the transitions $(2 \mathrm{~B} 2 \rightarrow 2 \mathrm{E})$ assuming a tetrahedral configuration. Based on which a tetrahedral geometry is suggested, $\mathrm{Cu}$-complex is paramagnetic complex, the obtained magnetic moment value 1.78 B.M and indicative of one unpaired electron per $\mathrm{Cu}$ (II) ion for d9-system suggesting tetrahedral structure. For Zn (II) complex, the electronic spectra of $\mathrm{Zn}$ (II) complex gave the absorption bands at the range $(500,675) \mathrm{nm}$, these bands can be assigned to $\mathrm{M} \rightarrow \mathrm{L}$ transition. The positions of these bands agree with low-spin tetrahedral geometry for Zn (II) complex. 


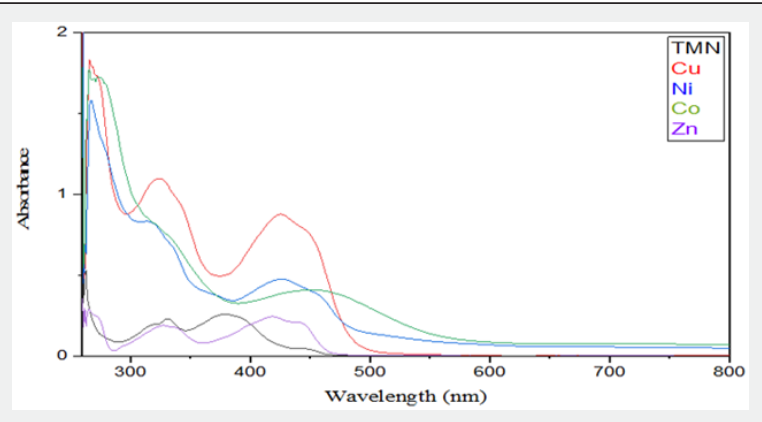

Figure 1: UV-Vis spectra of the synthesized Schiff base ligand (TMN) and its metal complexes.

\section{Mass Spectra of the Schiff Base Ligand (TMN)}

The mass spectrum of ligand (TMN) showed ion peak at m/e $=238$ as molecular peak of $(\mathrm{C} 13 \mathrm{H} 10 \mathrm{~N} 40)$. The ion peak at $\mathrm{m} / \mathrm{e}=$ $\mathrm{m} / \mathrm{z} 169(42 \%)$ is due to $\mathrm{M}+\left(\mathrm{C}_{12} \mathrm{H}_{11} \mathrm{~N}\right)$, while the ion peak at $\mathrm{m} / \mathrm{e}$ $=221.0(100 \%)$ corresponds to $\mathrm{M}+(\mathrm{C} 13 \mathrm{H} 10 \mathrm{~N} 4)$ which is the base peak, the ion peak at $\mathrm{m} / \mathrm{e}=170(9 \%)$ corresponds to $\mathrm{M}+\left(\mathrm{C}_{12} \mathrm{H}_{10} \mathrm{O}\right)$, the ion peak at $\mathrm{m} / \mathrm{e}=195(1.82 \%)$ is due to $\mathrm{M}+\left(\mathrm{C}_{12} \mathrm{H}_{9} \mathrm{~N}_{3}\right)$, the ion peak at $\mathrm{m} / \mathrm{e}=144(1.75 \%)$ points to $\mathrm{M}+\left(\mathrm{C}_{10} \mathrm{H}_{8} \mathrm{O}\right)$. The ion peak at $\mathrm{m} / \mathrm{e}=128(4.88 \%)$ refers to $\mathrm{M}+(\mathrm{C} 10 \mathrm{H} 8)$, the ion peak at $\mathrm{m} / \mathrm{e}$ $=78.11(2 \%)$ corresponds to $\mathrm{M}+\left(\mathrm{C}_{6} \mathrm{H}_{6}\right)$, the ion peak at $\mathrm{m} / \mathrm{e}=70$ $(20 \%)$ corresponds to $\mathrm{M}+\left(\mathrm{C}_{5} \mathrm{H}_{10}\right)$ and the ion peak at $\mathrm{m} / \mathrm{e}=52$ $(0.89 \%)$ corresponds to $\mathrm{M}+\left(\mathrm{C}_{4} \mathrm{H}_{4}\right)$. The fragmentation patterns of 1-((1H-1,2,4-triazol-3-ylimino) methyl) naphthalen-2-ol (TMN) are shown in Scheme 2 and (Figure 2).
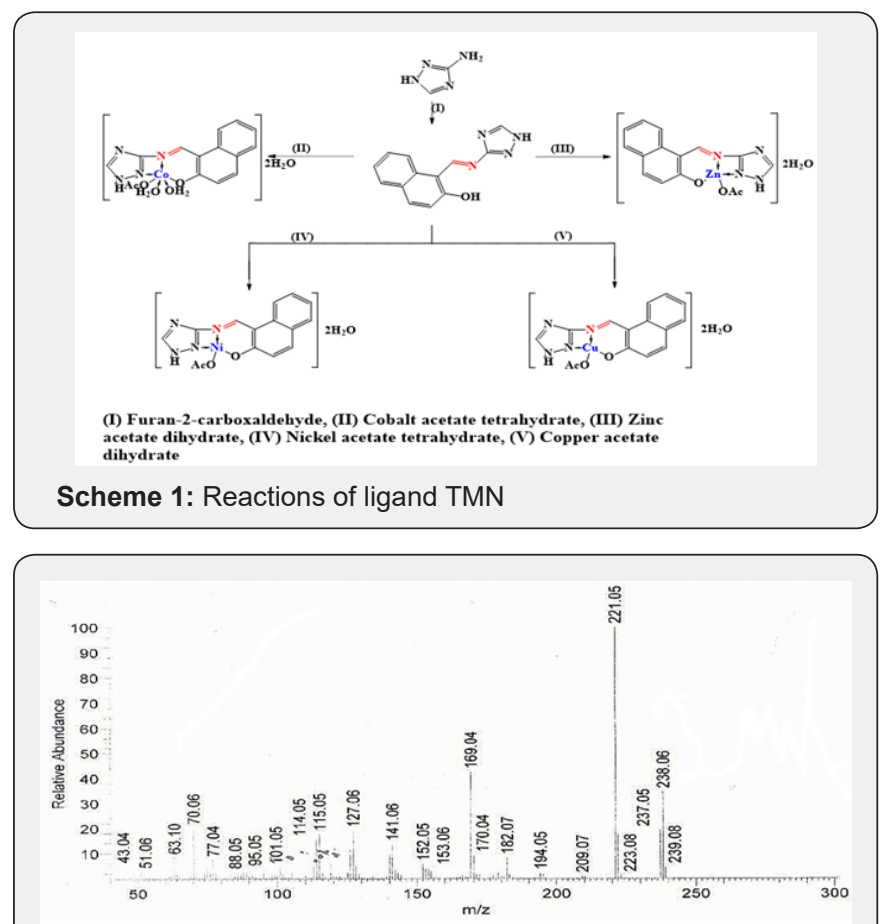

Figure 2: Mass spectra of the (TMN).

\section{HNMR}

The ${ }^{1} \mathrm{H}$ NMR spectral data of the synthesized Schiff base ligand (TMN) are given in (Figure 3). The appeared signals of all the pro- tons of Schiff base Ligand due to heteroaromatic/aromatic groups were found [40] as to be in their expected region. The spectra of the synthesized ligand (TMN) showed peaks at 7.14-7.14 ppm (d, $1 \mathrm{H}$, naphthalene $\mathrm{C} 3-\mathrm{H}), 7.37-7.41 \mathrm{ppm}(\mathrm{t}, 1 \mathrm{H}$, naphthalene $\mathrm{C6}-\mathrm{H})$, 7.56-7.6 ppm (t, $1 \mathrm{H}$, naphthalene $\mathrm{C} 7-\mathrm{H}), 7.84-7.86 \mathrm{ppm}(\mathrm{d}, 1 \mathrm{H}$ naphthalene C8-H), 8.29 ppm (s, 1H, triazole C-H), 10.05 ppm (s, $1 \mathrm{H}$, azomethine $\mathrm{C}-\mathrm{H}), 14.65 \mathrm{ppm}(\mathrm{s}, 1 \mathrm{H}, \mathrm{OH}), 14.19 \mathrm{ppm}(\mathrm{s}, 1 \mathrm{H}$, triazole $\mathrm{NH}$ ).

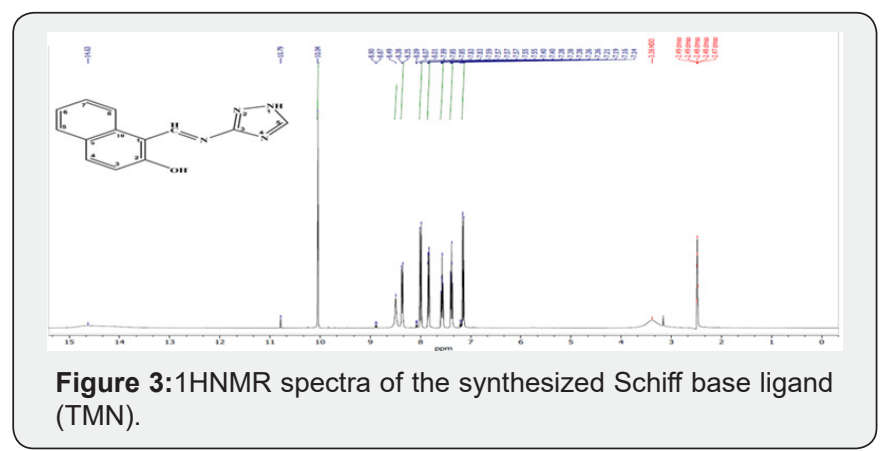

\section{CNMR}

The ${ }^{13} \mathrm{CNMR}$ spectra of the Schiff base ligand (TMN) were taken in DMSO-d6. The characteristic absorbtion13CNMR signals are given in Figure 4. The ${ }^{13} \mathrm{C}$ NMR spectral information is reported along with their possible assignments in the experimental section and all the carbons were found in the expected region [40-42]. The 13CNMR (DMSO) spectra of the synthesized TMN showed peaks at 109.291 ppm (C1 naphthalene), 120.386 ppm (C8 naphthalene), 120.699 ppm (C3 naphthalene), 124.39 ppm (C6 naphthalene), 127.829 ppm (C7 naphthalene), 128.973 ppm (C5 naphthalene), 129.248 ppm (C10 naphthalene), 132.191 ppm (C4 naphthalene), 133.015 ppm (C9 naphthalene), 146.284 ppm (C5 triazole), 164.509 ppm (C3 triazole), 165.638 ppm (C azomethine), 193.312 ppm (C2 naphthalene) (Figures $3 \& 4$ ).

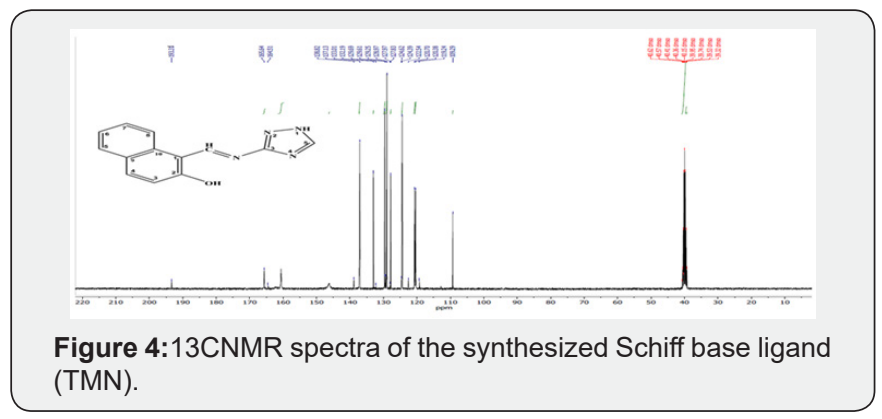

ESR Spectrum

Electron spin resonance (ESR) is a sensitive spectroscopic method for the determination of the geometric and electronic structure, the dynamics and the spatial distribution of paramagnetic species in materials. ESR directly focus on the unpaired electrons and nuclei in their vicinity and is, therefore, the method of choice for studying free radicals, triplet states, compounds with transition metals, rare earth ions, and defect centers. The ESR spectra of the powdered $\mathrm{Cu}^{\mathrm{II}}$ sample was carried out on Bruker- 
EMX-(Xbands-9.7 GHZ) spectrometer with 100KHZ frequency, microwave power 1.008MW, modulation/amplitude of 4 GAUSSES. The spectra of the complex exhibit a single anisotropic broad signal with hyperstructure indicating the contribution of free acetate ligand with complex formation. The ESR spectra of the $\mathrm{Cu}$ complex showed broad signals in (Figure 5). with two "g" values $(\mathrm{g} \backslash \backslash, \mathrm{g} \perp$ ). Generally, the $\mathrm{g} \backslash \backslash<\mathrm{g} \perp<2.3$, characteristic of complex with ${ }^{2} \mathrm{~B}_{1}(\mathrm{dx} 2-\mathrm{y} 2)$ orbital ground state. The average g value was calculated according to the equation gav $=1 / 3[\mathrm{~g} \backslash \backslash+2 \mathrm{~g} \perp]$ and it was equal to 2.15 for the prepared $\mathrm{Cu}$ complex. The $\mathrm{g} \backslash \backslash$ is a moderately function for covalent nature. The prepared cu-complex exhibited $\mathrm{g} \backslash \backslash$ at 2.05 which are less than 2.3 , suggesting the covalent character of copper - ligand bonds in the present complexes, where, $\mathrm{g} \backslash \backslash<$ 2.3 concerns ionic metal-ligand bond [43-48]. Fairly high values of $\mathrm{g}$ are in conformity with the oxygen, nitrogen and sulfur coordination in these compounds [44]. This coupling, known as the hyperfine interaction. The above complexes have a tetrahedral structure as indicated from the electronic absorption spectra.

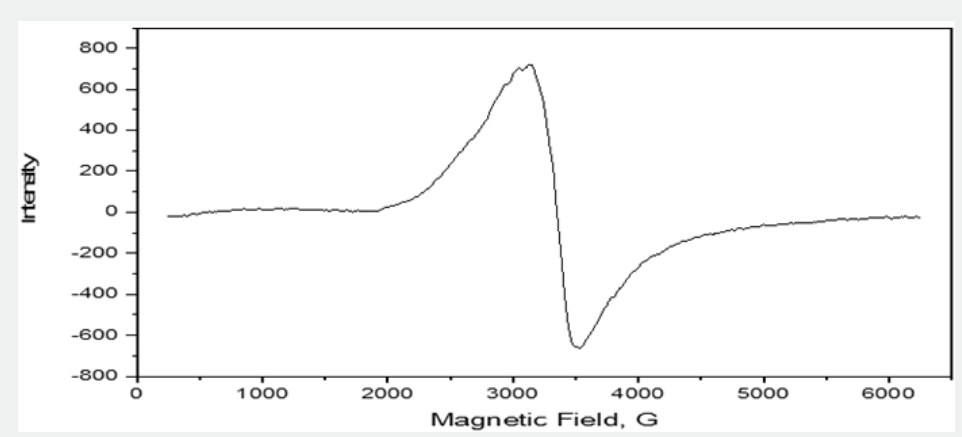

Figure 5:ESR spectra of the Cu complex.

\section{Thermal Analysis (TG)}

Table 4: Thermo-gravimetric data of the thermal decomposition of $\mathrm{Co}(\mathrm{II}), \mathrm{Ni}(\mathrm{II})$ and $\mathrm{Cu}(\mathrm{II})$ complexes of TMN.

\begin{tabular}{|c|c|c|c|c|c|c|c|c|}
\hline \multirow{2}{*}{$\begin{array}{l}\text { Compd. } \\
\text { No. }\end{array}$} & \multirow{2}{*}{ Molecular Formula } & \multirow{2}{*}{$\begin{array}{l}\text { Molecular } \\
\text { Weight }\end{array}$} & \multirow{2}{*}{ Steps } & \multicolumn{2}{|c|}{$\Delta \mathrm{T} \stackrel{\mathrm{o}}{\mathrm{C}}$} & \multicolumn{2}{|c|}{ mass \% } & \multirow{2}{*}{ Assignment } \\
\hline & & & & $\mathbf{T}^{\mathrm{i}}$ & $T_{f}$ & Calc. & Found & \\
\hline \multirow{4}{*}{ Co } & \multirow{4}{*}{$\mathrm{C}_{17} \mathrm{H}_{28} \mathrm{CoN}_{4} \mathrm{O}_{11}$} & \multirow{4}{*}{427.28} & $1^{\text {st }}$ & 49 & 120 & 8.43 & 6.9 & $2 \mathrm{H}_{2} \mathrm{O}$ \\
\hline & & & $2^{\text {nd }}$ & 170 & 300 & 8.43 & 7.6 & $2 \mathrm{H}_{2} \mathrm{O}$ \\
\hline & & & $3^{\text {rd }}$ & 373 & 470 & 69.32 & 65.109 & $\mathrm{CH}_{3} \mathrm{COO}, \mathrm{C}_{13} \mathrm{H}_{9} \mathrm{~N}_{4} \mathrm{O}$ \\
\hline & & & \multicolumn{3}{|c|}{ Residue } & 17.49 & 16.5 & $\mathrm{CoO}$ \\
\hline \multirow{3}{*}{$\mathrm{Ni}$} & \multirow{3}{*}{$\mathrm{C}_{15} \mathrm{H}_{16} \mathrm{~N}_{4} \mathrm{NiO}_{5}$} & \multirow{3}{*}{391} & $1^{\text {st }}$ & 47 & 130 & 10.11 & 9.2 & $2 \mathrm{H}_{2} \mathrm{O}$ \\
\hline & & & $2^{\text {nd }}$ & 190 & 380 & 68.62 & 71.7 & $\mathrm{CH}_{3} \mathrm{COO}, \mathrm{C}_{13} \mathrm{H}_{9} \mathrm{~N}_{4} \mathrm{O}$ \\
\hline & & & \multicolumn{3}{|c|}{ Residue } & 21.27 & 19.1 & $\mathrm{NiO}$ \\
\hline \multirow{4}{*}{$\mathrm{Cu}$} & \multirow{4}{*}{$\mathrm{C}_{15} \mathrm{H}_{16} \mathrm{CuN}_{4} \mathrm{O}_{5}$} & \multirow{4}{*}{395.86} & $1^{\text {st }}$ & 30 & 120 & 9.94 & 7.94 & $2 \mathrm{H}_{2} \mathrm{O}$ \\
\hline & & & $2^{\text {nd }}$ & 170 & 290 & 14.9 & 13.66 & $\mathrm{CH}_{3} \mathrm{COO}$ \\
\hline & & & $3^{\text {rd }}$ & 320 & 360 & 59.61 & 56.19 & $\mathrm{C}_{13} \mathrm{H}_{8} \mathrm{~N}_{4} \mathrm{O}$ \\
\hline & & & \multicolumn{3}{|c|}{ Residue } & 20.09 & 18.41 & $\mathrm{CuO}$ \\
\hline
\end{tabular}

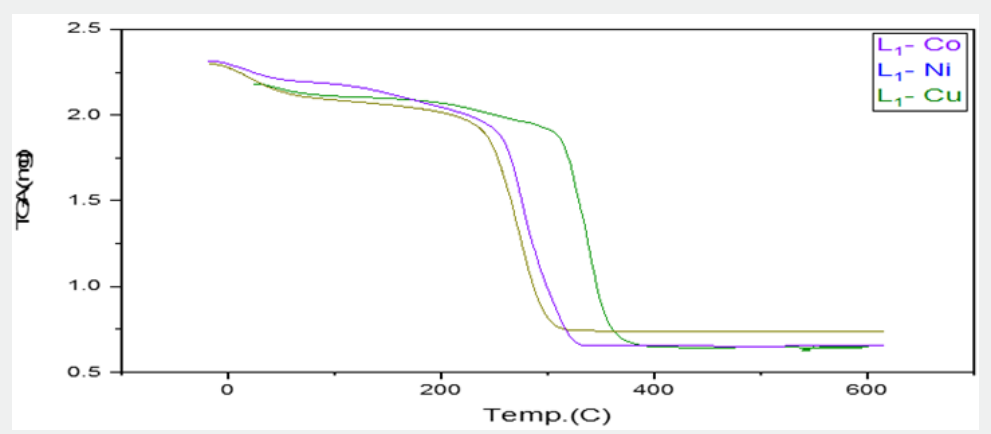

Figure 6:Thermal Gravimetric analysis (TGA) of $\mathrm{Co}, \mathrm{Ni}$ and $\mathrm{Cu}$ complexes of ligand (TMN). 
In the present investigation, the heating rates were suitably controlled at $10^{\circ} \mathrm{C} \mathrm{min}^{-1}$ under nitrogen atmosphere and the weight loss was measured from ambient temperature up to $800^{\circ} \mathrm{C}$. The TGA data of the thermal decomposition of the prepared complexes are shown in Table 4, Figure 6. and Scheme 2. The thermo-gram (TGA) data of CoII complex, exhibited three stages of decomposition. The first stage $\left(30-120^{\circ} \mathrm{C}\right)$ corresponds to the loss of two crystalline water molecules (found/calculated $=7.69 / 8.43$ $\%)$. The second step of decomposition $\left(230-337^{\circ} \mathrm{C}\right)$ may be due to the elimination of two coordinated water molecules (found/ calculated $=7.59 / 8.43 \%$ ), meanwhile the third stage refers to the decomposition of the complex with the formation of $\mathrm{CoO}$ as a final product (found/calculated $=15.2 / 17.49 \%$ ). For NiII complex, the first stage in temperature range $\left(40-130^{\circ} \mathrm{C}\right)$ corresponds to the loss of two crystalline water molecules (found/calculated = $10.11 / 9.20 \%$ ), while the final stage refers to the decomposition of one acetate group and the organic part leaving the metal oxide $\mathrm{NiO}$ as a residue (Found/Calculated $=20.27 / 19.1$ ). The TGA data of CuII complex, revealed three stages of decomposition. The first stage $\left(50-120^{\circ} \mathrm{C}\right)$ related to the loss of two crystalline water molecules (found/calculated $=15.6 / 16.67 \%$ ). The second step of degradation $\left(170-290^{\circ} \mathrm{C}\right)$ corresponds to the elimination of one acetate group (found/calculated $=11.9 / 10.38 \%$ ). The final stage detected at $290-360^{\circ} \mathrm{C}$ point to the gradual decomposition of the complex with the formation of $\mathrm{CuO}$ at the final stage (found/calculated $=18.41 / 20.09 \%$ ).

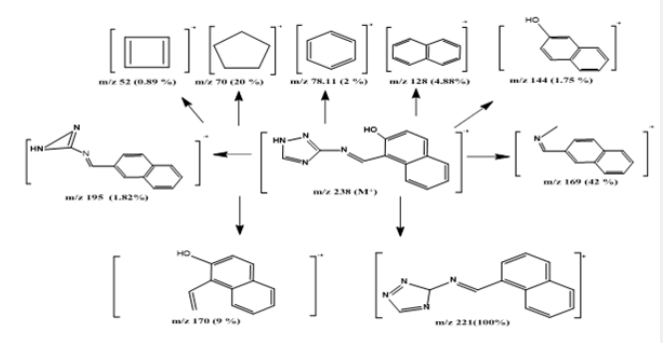

Scheme 2: Proposed mass fragmentation pattern of the ligand (TMN).
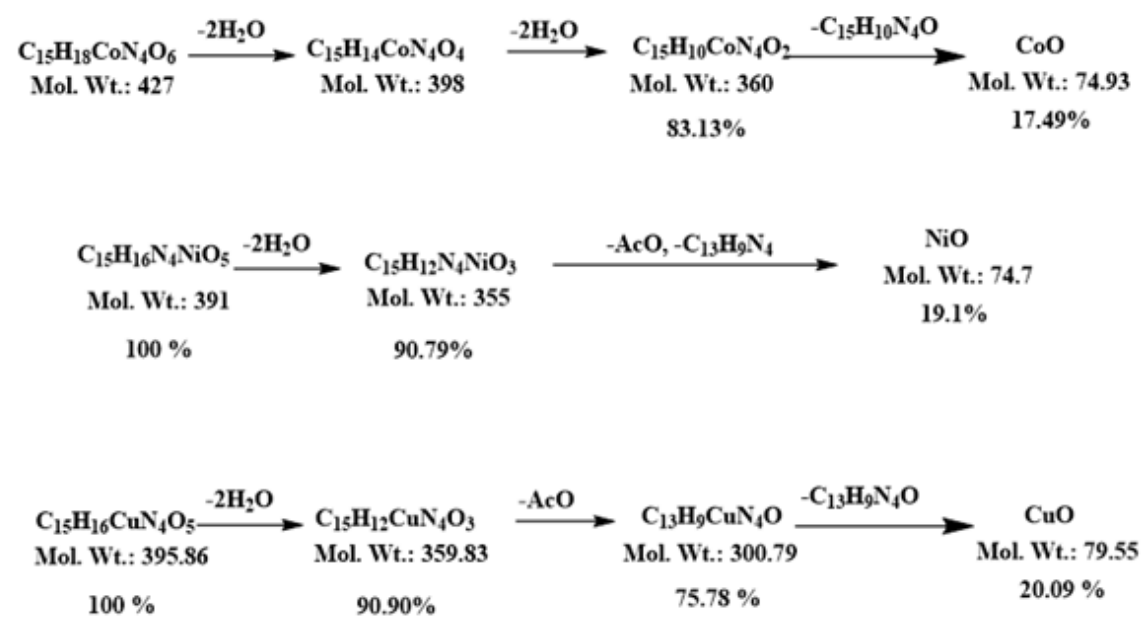

Scheme 3: Thermal decomposition of $\mathrm{Co}, \mathrm{Ni}$, and $\mathrm{Cu}$ complexes.

\section{Thermo-kinetic Parameters}

Table 5: Thermodynamic data of the thermal decomposition of $\mathrm{Co}(\mathrm{II}), \mathrm{Ni}(\mathrm{II})$ and $\mathrm{Cu}(\mathrm{II})$ complexes of TMN.

\begin{tabular}{|c|c|c|c|c|c|c|c|c|c|c|c|c|c|}
\hline \multirow{3}{*}{ Comp. } & \multirow{3}{*}{ Steps } & \multicolumn{6}{|c|}{ Coats Redfern } & \multicolumn{6}{|c|}{ Horowitz-Metzger } \\
\hline & & \multirow[b]{2}{*}{$\mathbf{R}^{2}$} & $\mathbf{E a}$ & $\mathbf{A}$ & $\Delta \Sigma *$ & $\Delta \mathbf{H} *$ & $\Delta \Gamma *$ & \multirow[b]{2}{*}{$\mathbf{R}^{2}$} & Ea & A & $\Delta \Sigma *$ & $\Delta \mathbf{H} *$ & $\Delta \Gamma ?$ \\
\hline & & & $\mathrm{KJ} \mathrm{mol}^{-1}$ & $S^{-1}$ & $\begin{array}{c}\mathrm{mol}^{-1} \\
\mathbf{K}^{-1}\end{array}$ & $\mathrm{KJ} \mathrm{mol}^{-1}$ & $\mathrm{KJ} \mathrm{mol}^{-1}$ & & $\begin{array}{c}\mathrm{KJ} \\
\mathrm{mol}^{-1}\end{array}$ & $S^{-1}$ & $\begin{array}{c}\mathrm{mol}^{-1} \\
\mathbf{K}^{-1}\end{array}$ & $\mathrm{KJ} \mathrm{mol}^{-1}$ & KJ $\mathrm{mol}^{-1}$ \\
\hline \multirow{3}{*}{$\mathrm{Co}^{\mathrm{II}}$} & $1^{\text {st }}$ & 0.96 & 77410 & $2.39 \times 10^{10}$ & -47 & 74453 & 91503 & 0.96 & 30205 & $1.03 \times 10^{4}$ & -169 & 27312 & 86277 \\
\hline & $2^{\text {nd }}$ & 0.99 & 55375 & $6.81 \times 10^{14}$ & -240 & 51148 & 173240 & 0.99 & 32183 & $3.06 \times 10^{2}$ & -229 & 27959 & 144400 \\
\hline & $3^{\text {rd }}$ & 0.99 & 186436 & $3.55 \times 10^{13}$ & 7.48 & 180670 & 175484 & 0.99 & 95826 & $4.01 \times 10^{6}$ & -125 & 90065 & 177059 \\
\hline
\end{tabular}




\section{Organic and Medicinal Chemistry International Journal}

\begin{tabular}{|c|c|c|c|c|c|c|c|c|c|c|c|c|c|}
\hline \multirow{2}{*}{$\mathrm{Ni}{ }^{I I}$} & $1^{\text {st }}$ & 0.98 & 51926 & $2.99 \times 10^{6}$ & -122 & 48931 & 93045 & 0.98 & 21549 & $2.68 \times 10^{2}$ & -200 & 18556 & 90569 \\
\hline & $2^{\text {nd }}$ & 0.88 & 39663 & $1.17 \times 10^{16}$ & 57 & 35037 & 3053 & 0.96 & 25701 & $2.60 \times 10^{1}$ & -223 & 21078 & 145094 \\
\hline \multirow{3}{*}{$\mathrm{Cu}^{\mathrm{II}}$} & $1^{\text {st }}$ & 0.93 & 36405 & $4.58 \times 10^{4}$ & -156 & 33510 & 88144 & 0.92 & 18123 & $9.46 \times 10^{1}$ & -208 & 15230 & 87757 \\
\hline & $2^{\text {nd }}$ & 0.99 & 49818 & $6.72 \times 10^{5}$ & -213 & 45533 & 155437 & 0.99 & 26460 & $5.8 \times 10^{1}$ & -242 & 22179 & 147315 \\
\hline & $3^{\text {rd }}$ & 0.99 & 1164986 & $7.023 \times 10^{94}$ & 1565 & 1160069 & 234924 & 0.99 & 522706 & $2.85 \times 10^{46}$ & 638 & 517792 & 140234 \\
\hline
\end{tabular}

The thermodynamic activation parameters of decomposition processes of dehydrated complexes namely activation energy ( $\left.\mathrm{E}^{*}\right)$, enthalpy $\left(\Delta \mathrm{H}^{*}\right)$, entropy $\left(\Delta \mathrm{S}^{*}\right)$ and Gibbs free energy change of the decomposition $\left(\Delta \mathrm{G}^{*}\right)$ are evaluated graphically by employing the Coats-Redfern [49] relation and Horowitz-Metzger [50]. Kinetic parameters of different stages are summarized in Table 5, together with the radii of metal ions. The results showed that the values obtained by various methods are comparable and were in harmo-

ny with each other. The kinetic and thermodynamic parameters were determined by non-isothermal methods. The thermodynamic activation parameters for the thermal decomposition steps in complexes were calculated using the relationships:

$$
\begin{aligned}
& \Delta \mathrm{H}^{*}=\mathrm{E}^{*}-\mathrm{RT} \\
& \Delta \mathrm{S}^{*}=\mathrm{R}[\ln (\mathrm{Ah} / \mathrm{kT})-1] \\
& \Delta \mathrm{G}^{*}=\Delta \mathrm{H}^{*}-\mathrm{T} \Delta \mathrm{S}^{*}
\end{aligned}
$$

\begin{tabular}{|c|c|c|c|c|c|c|}
\hline \multirow{4}{*}{ Compd. } & \multicolumn{6}{|c|}{ Recorded zone diameter ( $\mathrm{mm}$ ) for each test microorganism } \\
\hline & \multicolumn{4}{|c|}{ sBacteria } & \multirow{2}{*}{\multicolumn{2}{|c|}{ Fungi }} \\
\hline & \multicolumn{2}{|c|}{ Gram-Positive } & \multicolumn{2}{|c|}{ Gram-Negative } & & \\
\hline & Bacillus subtillus & $\begin{array}{c}\text { Staphylococcus } \\
\text { aureus }\end{array}$ & Escherichia & Salmonella & $\begin{array}{l}\text { Aspergillus fumi- } \\
\text { gatus }\end{array}$ & Candida albicans \\
\hline & $\begin{array}{c}\text { RCMB } 015 \text { (1) } \\
\text { NRRL B-543 }\end{array}$ & (RCMB010010) & Coli & Typhimurium & (RCMB 002008) & $\begin{array}{l}\text { RCMB } 005003(1) \\
\quad \text { ATCC } 10231\end{array}$ \\
\hline & & & $\begin{array}{l}\text { (RCMB 010052) } \\
\text { ATCC } 25955\end{array}$ & $\begin{array}{c}\text { RCMB } 006(1) \\
\text { ATCC } 14028\end{array}$ & & \\
\hline TMN & 9 & NA & NA & NA & 17 & 15 \\
\hline $\mathrm{Zn}$ & 15 & 13 & 14 & NA & 16 & 14 \\
\hline \multirow[t]{2}{*}{ St. } & 26 & 24 & 30 & 17 & 17 & 20 \\
\hline & Gentamycin & & Gentamycin & & Ketoconazole & \\
\hline
\end{tabular}

Table 6: The antimicrobial activity of the ligand and its $\mathrm{Zn}(\mathrm{II})$ complex.

where $\mathrm{k}$ is Boltezmann constant and h is Plank's constant, A is the frequency factor and $\mathrm{R}$ is the gas constant. From the results listed in Table 6, we get conclusions as follows:

The negative values of activation entropies $\Delta S^{*}$ indicate the reactions are slow and the products more stable than reactants [51], while the positive values of $\Delta \mathrm{S}^{*}$ indicate that the activated complexes for this decomposition stage have a less ordered structure compared to the reactant. Further, the reaction may be described as faster than normal. The positive values of the $\Delta \mathrm{H}^{*}$ mean that the decomposition processes are endothermic [52]. The values of $\Delta \mathrm{G}^{*}$ increases significantly for the subsequent decomposition stages, increasing the values of $\Delta \mathrm{G}^{*}$ as going from one decomposition step subsequently to another reflects that the rate of removal of the subsequent ligand will be lower than that of the precedent ligand and the reactions are non-spontaneous (Table 5).

\section{Biological Activity}

\section{Antimicrobial Activity}

To contribute to the field of bioinorganic chemistry, the synthesized ligand and its $\mathrm{Zn}(\mathrm{II})$ complex were tested against bac- terial and fungal strains by disc diffusion method. The microorganisms used in the present investigations included bacterial and fungal strains. Bacterial strains; Gram-positive bacteria (Staphylococcus aureus (RCMB010010) and Bacillus Subtillus RCMB 015 (1) NRRL B-543 Gram-negative bacteria (Escherichia Coli (RCMB 010052) ATCC 25955and fungal strains; Aspergillus fumigatus (RCMB 002008) and Candida albicans RCMB 005003 (1) ATCC 10231. The results were compared with those of the standard drugs (Gentamicin for Gram-positive bacteria and Gram-negative bacteria and Ketoconazole for fungal strains) and calculated the diameter of inhibition zone for each by $\mathrm{mm}$. The antimicrobial results evidently show that the triazole derivatives and its complexes possess a broad spectrum of activity against the tested organisms.

\section{Antimicrobial activity of Ligand and its Zn(II) complex}

The antimicrobial activity of ligand (TMN) and its Zn(II) complex against the bacterial and fungal strains were tested and evaluated. Table 6 shows the antimicrobial activity of ligand against the tested bacterial and fungal strains. Our results showed no in- 
hibition effect on the growth of the bacterial and fungal strains by the ligand excepted the effect on the growth of Bacillus subtillus RCMB 015 (1) NRRL B-543, Aspergillus fumigatus (RCMB 002008) and Candida albicans RCMB 005003 (1) ATCC 10231 with inhibition zones $9 \mathrm{~mm}, 17 \mathrm{~mm}$ and $15 \mathrm{~mm}$, respectively. While the Zn (I) complex exhibited good antimicrobial activity against both bacteria (Gram-negative \& Gram-positive bacteria) and fungal strains. It showed higher antibacterial activity against Bacillus subtillus RCMB 015 (1) NRRL B-543, Staphylococcus aureus (RCMB010010) and Escherichia Coli (RCMB 010052) ATCC 25955 with inhibition zone $15 \mathrm{~mm}, 13 \mathrm{~mm}$ and $14 \mathrm{~mm}$ respectively, while appearance moderated to weak activity against Aspergillus fumigatus (RCMB 002008) and Candida albicans RCMB 005003 (1) ATCC 10231 with inhibition zone 16 and $14 \mathrm{~mm}$, respectively. Hence the antimicrobial activity after complexation with $\mathrm{Zn}(\mathrm{II})$ is enhanced as compared to that of the free ligand.

\section{Conclusion}

Using the microwave method assures the principals of green chemistry. The structure of the prepared compounds was spectroscopically illustrated by FT-IR, NMR, Mass, and elemental analysis. The newly synthesized Schiff bases ligand obtained from 3-amino-1,2,4-triazole with 2-hydroxy-1-naphthaldehyde using microwave technique act as bidentate and tridentate ligand, which coordinated through the azomethine- $\mathrm{N}$, methoxy-O and triazole ring to the metal ions; $\mathrm{Co}(\mathrm{II}), \mathrm{Ni}(\mathrm{II}), \mathrm{Cu}(\mathrm{II})$ and $\mathrm{Zn}(\mathrm{II})$. The thermal dehydration and decomposition of $\mathrm{Cu}(\mathrm{II})$ complex show elimination of water, acetate then organic content and MO remained as a residue. The antimicrobial activity of the Schiff base ligand (TMN) and its $\mathrm{Zn}$ (II) complex against the bacterial and fungal strains showed that the activity of the ligand after complexation with Zn(II) is enhanced as compared to that of the free ligand.

\section{References}

1. Anastas P, Eghbali N (2010) Green chemistry: principles and practice. Chemical Society Reviews, 39(1): 301-312.

2. De la Hoz A, Loupy A (2013) Microwaves in organic synthesis, 2 volume set: John Wiley \& Sons United States.

3. Kappe CO, Stadler A, Dallinger D (2012) Microwave theory. Microwaves in Organic and Medicinal Chemistry, $2^{\text {nd }}$ edn): 9-39.

4. Ameta SC, Punjabi PB, Ameta R, Ameta C (2014) Microwave-assisted organic synthesis: a green chemical approach: CRC Press, USA .

5. Horikoshi S, Serpone N (2013) Microwaves in nanoparticle synthesis: fundamentals and applications: John Wiley \& Sons, USA.

6. De Souza, ROMA (2015) Theoretical Aspects of Microwave Irradiation Practices. In Production of Biofuels and Chemicals with Microwave. Dordrecht: Springer 3-16.

7. Chemat F, Cravotto G (2013) Microwave-assisted extraction for bioactive compounds. Theory and practice. Springer.

8. Ehsan S, Ishfaq A, Khan B, Saghir T, Ghafoor S (2012) Conventional \& Microwave-Assisted Synthesis and Antimicrobial Evaluation of Pyrimidine Azo Compounds. International J. of science and research 3(12): 368-373

9. Abo Dena AS (2014) To the memory of Hugo Schiff: Applications of Schiff bases in potentiometric sensors. Russian Journal of Applied Chemistry 87(3): 383-396.
10. Ashraf MA, Mahmood K, Wajid A, Maah MJ, Yusoff I (2011) Synthesis, characterization and biological activity of Schiff bases. IPCBEE 10: 1-7.

11. Boceiri N, Benabdallah T, Youcef MH, Reffas H (2016) Synthesis and Characterization of a Novel Series of Amphiphilic Mercapto-1, 2, 4-Triazole Schiff Base Ligands: Investigation of their Behavior in Hydro-Organic Solutions. Journal of Surfactants and Detergents 19(3): 583-597.

12. Al-Shemary RK, Al-khazraji AM, Niseaf AN (2016) Preparation, spectroscopic study of Schiff base ligand complexes with some metal ions and Evaluation of antibacterial activity. The Pharma Innovation 5(1, Part B): 81.

13. Bader NR (2010) Applications of Schiff's bases chelates in quantitative analysis: A review. Rasayan Journal of Chemistry 3(4): 660-670.

14. Mohamed SA, Ahmed AO, Humada AA (2009) Synthesis and Characterization of Some Schiff Bases (derived from thiazole) and Their Complexes with Co (II), Ni (II) and Cu (II). Journal of Kirkuk University-Scientific Studies 4(2): 37-45.

15. Balabin RM (2009) Tautomeric equilibrium and hydrogen shifts in tetrazole and triazoles: Focal-point analysis and ab initio limit. The Journal of chemical physics 131(15): 154307.

16. Kavaklı C, Kavaklı PA, Güven O (2014) Preparation and characterization of glycidyl methacrylate grafted 4-amino-1, 2, 4-triazole modified nonwoven fiber adsorbent for environmental application. Radiation Physics and Chemistry 94: 111-114.

17. Shuklaa PK, Sonia N, Vermaa A, Jhab AK (2014) Synthesis, characterization and in vitro biological evaluation of a series of 1 , 2, 4-triazoles derivatives \& triazole based schiff bases. Der Pharma Chemica 6(3): 153-160.

18. Hanif M, Saleem M, Hussain MT, Rama NH, Zaib S, Aslam MAM, et al. (2012) Synthesis, urease inhibition, antioxidant and antibacterial studies of some 4-amino-5-aryl-3H-1, 2, 4-triazole-3-thiones and their 3, 6-disubstituted 1, 2, 4-triazolo [3, 4-b] 1, 3, 4-thiadiazole derivatives. Journal of the Brazilian Chemical Society 23(5): 854-860.

19. Maste MM, Ainapure R, Patil PB, Bhat AR (2011) Triazolone and their derivatives for anti-tubercular activities. Asian J Research Chem 4(7): 1050-1054.

20. Kamal A, Syed MAH, Mohammed SM (2015) Therapeutic potential of benzothiazoles: a patent review (2010-2014). Expert opinion on therapeutic patents 25(3): 335-349.

21. Sripriya S, Subha C, Selvaraj A (2013) The inhibition chemistry of 2-amino, 5-phenyl 1, 3, 4-triazole for aluminium in hydrochloric acid solution. IOSR-Journal of Applied Chemistry 6(2): 25-29.

22. Murtaza S, Akhtar MS, Kanwal F, Abbas A, Ashiq S, et al. (2017) Synthesis and biological evaluation of schiff bases of 4-aminophenazone as an anti-inflammatory, analgesic and antipyretic agent. Journal of Saudi Chemical Society 21(1): S359-S372.

23. Abdulrasool MM, Jawad AH, Shneine JK (2012) Synthesis, characterization and evaluation of biological activity of new heterocyclic compounds containing 1,2,4-triazoleand 1,3, 4-thiadiazole rings. International Journal of Applied Science and Technology 2(10): 155-164.

24. Sahoo S, Patwari K, Kumar C, Setty CM (2013) Synthesis and Biological Activity of Certain Mannich Bases Derivatives from 1, 2, 4-Triazoles. Iranian Journal of Pharmaceutical Sciences 9(4): 51-60.

25. Al-Khuzaie MG, Al Majidi SM (2014) Synthesis, characterization and evaluation antimicrobial activity of some new substituted 2-mercapto3-phenyl-4 (3H)-quinazolinone. Iraqi Journal of Science, 55: 582-593.

26. Refaee M, Abou-Elmagd W, El-Shahawi M, Hekal M (2014) Novel Fused and Spiro Heterocyclic Compounds Derived from 4-(4-amino5-mercapto-4H-1, 2, 4-triazol-3-yl) phthalazin-1 (2H)-one. European Chemical Bulletin 3(7): 723-728. 
27. Jassim WK, Fayad AA, Jassim IK (2011) Synthesis and characterization of some substituted heterocyclic compounds and evaluation of biological activity. karbala journal of pharmaceutical sciences 2: 228240

28. Hou YP, Sun J, Pang ZH, Lv PC, Li DD, et al. (2011) Synthesis and antitumor activity of 1, 2, 4-triazoles having 1, 4-benzodioxan fragment as a novel class of potent methionine aminopeptidase type II inhibitors. Bioorganic \& medicinal chemistry 19(20): 5948-5954.

29. Baviskar BA, Khadabadia SS, Deore SL, Shiradkar MR (2012) Synthesis of clubbed triazolyl indeno [1, 2-C] isoquinolines as a novel anticancer agent. Der Pharmacia Sinica 3(1): 24-30.

30. Kattimani PP, Kamble RR, Kariduraganavar MY, Dorababu A, Hunnur RK (2013) Synthesis, characterization and in vitro anticancer evaluation of novel 1, 2, 4-triazolin-3-one derivatives. European Eur J Med Chem 62: $232-240$.

31. Hameed AA, Hassan F (2014) Synthesis, Characterization and Antioxidant Activity of Some 4-Amino-5-Phenyl-4h-1, 2, 4-Triazole-3Thiol Derivatives. International Journal of Applied 4(2): 202-211.

32. Mousa MN, Al-jadaan SA (2012) Evaluation of The Anti-Inflammatory Activity and Ulcerogenic Liability of 5-(3-Chloro-1-benzothien-2yl)-4-phenyl-4H-1, 2, 4-triazole-3-thiol. Basrah Journal of Veterinary Research 11(1): 122-127.

33. Akhter MW, Hassan MZ, Amir M (2014) Synthesis and pharmacological evaluation of 3-diphenylmethyl-6-substituted-1, 2, 4-triazolo [3, 4-b]1, 3, 4-thiadiazoles: A condensed bridgehead nitrogen heterocyclic system. Arabian Journal of Chemistry 7(6): 955-963.

34. Pandey V, Chawla V, Saraf SK (2012) Comparative study of conventional and microwave-assisted synthesis of some Schiff bases and their potential as antimicrobial agents. Medicinal Chemistry Research, 21(6): 844-852.

35. Abdullah HM, Jassim IK, Safi MN (2014) Synthesis and characterization of new heterocyclic compounds with studying its biological activity. karbala journal of pharmaceutical sciences 4:119-135

36. Hassan A, Heakal B, Younis A, Bedair M, Elbialy Z, Abdelsalam M (2019) Synthesis of Some Triazole Schiff Base Derivatives and Their Metal Complexes under Microwave Irradiation and Evaluation of Their Corrosion Inhibition and Biological Activity. Egypt J Chem 62: 1-21.

37. Furniss BS (1989) Vogel's textbook of practical organic chemistry: Pearson Education India Cooper R, Kavanagh F Analytical microbiology 1(2): 1972

38. Kiehlbauch JA, Hannett GE, Salfinger M, Archinal W, Monserrat C et al. (2000) Use of the National Committee for Clinical Laboratory Standards Guidelines for Disk Diffusion Susceptibility Testing in New York State Laboratories. J Clin Microbiol 38(9): 3341-3348.
39. Cooper R, Kavanagh F (1972) Analytical microbiology 1(2)

40. Yoe JH, Jones AL (1944) Colorimetric determination of iron with disodium-1, 2-dihydroxybenzene-3, 5-disulfonate. Industrial \& Engineering Chemistry Analytical Edition 16(2): 111-115.

41. Chohan ZH, Sumrra SH, Youssoufi MH, Hadda T B (2010) Design and synthesis of triazole Schiff bases and their oxovanadium (IV) complexes as antimicrobial agents. Journal of Coordination Chemistry, 63(22): 3981-3998.

42. Prashanthi Y, Raj S (2010) Synthesis and characterization of transition metal complexes with N, O; N, N and S, N-donor Schifff base ligands. Journal of Scientific Research 2(1): 114-126.

43. Gup R, Gökçe C, Dilek N (2015) Synthesis, structural characterization and DNA interaction of zinc complex from 2, 6-diacetylpyridine dihydrazone and \{4-[(2E)-2-(hydroxyimino) acetyl] phenoxy\} acetic acid. Journal of Photochemistry and Photobiology B: Biology 144: 42 50 .

44. Kivelson D, Neiman R (1961) ESR studies on the bonding in copper complexes. The Journal of Chemical Physics 35(1): 149-155.

45. Lever ABP (1968) Inorganic electronic spectroscopy. Journal of chemical education 46(9): A628.

46. Calle C, Eichel R A, Finazzo C, Forrer J, Granwehr J, Gromov I, et al. (2001) Electron paramagnetic resonance spectroscopy. CHIMIA International Journal for Chemistry 55(10): 763-766.

47. Fouda MFR, Abd-Elzaher MM, Shakdofa MME, El Saied FA, Ayad MI, et al. (2008) Synthesis and characterization of transition metal complexes of $\mathrm{N}^{\prime}$-[(1, 5-dimethyl-3-oxo-2-phenyl-2, 3-dihydro-1H-pyrazol-4-yl] methylene] thiophene-2-carbohydrazide. Transition Metal Chemistry 33(2): 219-228.

48. Carrington A, McLachlan AD (1967) Introduction to magnetic resonance: with applications to chemistry and chemical physics 44(12): 772

49. Coats AW, Redfern JP (1964) Kinetic parameters from thermogravimetric data. Nature 201(4914): 68-69.

50. Horowitz HH, Metzger GA (1963) new analysis of thermogravimetric traces. Analytical chemistry, 35(10): 1464-1468.

51. Frost AA, Pearson RG (1961) New York. Kinetics and Mechan ism. John Wiley and Sons. Inc New York: 480.

52. El-Ayaan U, Kenawy I, El-Reash YA (2007) Synthesis, thermal and spectral studies of first-row transition metal complexes with girard $P$ reagent-based ligand. Spectrochimica Acta Part A: Molecular and Biomolecular Spectroscopy 68(2): 211-219.

\section{Your next submission with Juniper Publishers will reach you the below assets}

- Quality Editorial service

- Swift Peer Review

- Reprints availability

- E-prints Service

- Manuscript Podcast for convenient understanding

- Global attainment for your research

- Manuscript accessibility in different formats

( Pdf, E-pub, Full Text, Audio)

- Unceasing customer service

Track the below URL for one-step submission https://juniperpublishers.com/online-submission.php 